Article

\title{
Pt Nanoclusters Anchored on Hollow Ag-Au Nanostructures for Electrochemical Oxidation of Methanol
}

\author{
Xinghe Li ${ }^{1,+}$, Xinyu Qin ${ }^{1,+}{ }^{\mathbb{C}}$, Bingyi Yan ${ }^{1,+} \mathbb{C}$, Huiling Huang ${ }^{1}$, Wang Zhang ${ }^{2}$ \\ and Yuanzhe Piao ${ }^{1,3, *}$ \\ 1 Program in Nano Science and Technology, Graduate School of Convergence Science and Technology, \\ Seoul National University, 145 Gwanggyo-ro, Yeongtong-gu, Suwon-si 16229, Gyeonggi-do, Korea; \\ xinghelee@snu.ac.kr (X.L.); xinyuqin@snu.ac.kr (X.Q.); bingyiyan@snu.ac.kr (B.Y.); \\ huilingyong@snu.ac.kr (H.H.) \\ 2 School of Chemistry and Chemical Engineering, Yangzhou University, Yangzhou 225002, China; \\ zhangwang@yzu.edu.cn \\ 3 Advanced Institutes of Convergence Technology, 145 Gwanggyo-ro, Yeongtong-gu, \\ Suwon-si 16229, Gyeonggi-do, Korea \\ * Correspondence: parkat9@snu.ac.kr; Tel.: +82-31-888-9141 \\ + Theses authors contributed equally to this work.
}

Received: 10 October 2020; Accepted: 7 December 2020; Published: 9 December 2020 updates

\begin{abstract}
The synthetic method of Pt nanocluster-anchored hollow Ag-Au nanostructures and measurements of their electrocatalytic properties for methanol oxidation reaction (MOR) are reported here. In this synthesis, uniform $\mathrm{Ag}$ nanospheres were prepared by reduction of silver nitrate $\left(\mathrm{AgNO}_{3}\right)$ with sodium borohydride $\left(\mathrm{NaBH}_{4}\right)$ and then hollow $\mathrm{Ag}$-Au nanostructures were synthesized via galvanic replacement of the as-prepared $\mathrm{Ag}$ nanospheres with $\mathrm{Au}^{3+}$. Finally, the reduction of potassium tetrachloroplatinate (II) $\left(\mathrm{K}_{2} \mathrm{PtCl}_{4}\right)$ with ascorbic acid was performed to deposit $\mathrm{Pt}$ nanoclusters on the surface of hollow $\mathrm{Ag}$ - $\mathrm{Au}$ nanostructures. The hollow interior of $\mathrm{Pt}$ nanocluster-anchored Ag-Au nanostructures and change in the size of Pt nanoclusters by varying the injected molar ratio of $\mathrm{Pt} / \mathrm{Au}$ were observed by transmission electron microscopy (TEM). Moreover, other morphological, compositional, and optical information of the obtained nanoscale materials were analyzed by $X$-ray diffraction analysis (XRD), inductively coupled plasma mass spectrometry (ICP-MS), and ultraviolet-visible spectroscopy (UV-vis). The electrocatalytic ability of the obtained $\mathrm{Pt}$ nanocluster-anchored hollow Ag-Au nanostructures toward MOR was confirmed by the results of cyclic voltametric (CV) measurements. The ease of three-step synthetic strategy and good electrocatalytic performance of the Pt nanocluster-anchored hollow Ag-Au nanostructures displayed their promising potential in the use of electrochemical oxidation of methanol.
\end{abstract}

Keywords: Pt nanoclusters; hollow Ag-Au nanostructures; galvanic replacement; methanol electrochemical oxidation

\section{Introduction}

Severe energy problems have attracted increasing attention recently, and direct methanol fuel cells (DMFCs) are regarded as one of the new energy resources, with their advantages of high power density, low operating temperatures, convenient transportations of methanol, etc. [1-4]. For DMFCs, platinum is the most important and frequently applied metal element for catalytic applications, and Pt-based catalyst has been a popular issue in the research realm of DMFCs. However, some factors restrict the practical and comprehensive applications of Pt-based catalysts in DMFCs. One of the factors is catalyst 
poisoning effect caused by carbon monoxide $(\mathrm{CO})$ which forms in the methanol oxidation reaction (MOR) as one kind of intermediate product and firmly attaches to the surface of Pt portion, leading to fewer available active sites of $\mathrm{Pt}$ [5-8]. Another thing that limits the extensive use of Pt-based catalysts is the extravagant price [9-11].

To overcome the two primary limits, one of the typical synthetic strategies for enhancing the electrocatalytic activity of Pt-based catalysts is combining Pt with other materials, such as dispersing Pt contents onto diverse supporters such as carbon material [12-15] and noble metallic nanoparticles, [11,16-21] or alloying Pt with other metal such as Pd [22,23], Ru [24,25], Rh [26], etc [27-32]. Recently, many advances in the synthetic approaches of Pt-based electrode materials with hollow structures have broadly demonstrated their great potential for MOR. Owing to the high surface-to-volume-ratios, elevated use of $\mathrm{Pt}$, and abundant active sites, hollow structures have received much attention $[33,34]$. For instance, $\mathrm{Hu}$ and colleagues applied a galvanic replacement approach to synthesize a novel graphene-supported hollow Pt-Ni nanocatalyst, which exhibits high activity toward the MOR because of unique hollow structure and the synergistic effect between $\mathrm{Pt}$ and $\mathrm{Ni}$ [35]. More recently, Geng's team fabricated hollow Pt-Pd structures with high active surface areas, which presents a good catalytic activity and stability toward MOR [36].

Moreover, for lower usage of noble metal and a further increase of surface area, galvanic replacement is the typically used method for fabricating hollow nanostructures [37,38]. In galvanic replacement reaction, the difference of redox potential between sacrificial metallic templates, such as $\mathrm{Ag}[39-42], \mathrm{Co}[43,44], \mathrm{Ni}[35,45]$ and substitutive metal ions is the reason galvanic replacement reaction could occur spontaneously [46]. Moreover, numerous reports of galvanic replacement between $\mathrm{Ag}$ nanoparticles with $\mathrm{HAuCl}_{4}$ were reported [47-49].

It is worth mentioning that designing core-shell Pt-based nanostructures is a significant way of reducing the Pt loading in fuel cell systems and ameliorating both catalytic performance and stability [50]. Therefore, research about synthesizing Au-Pt nanoscale materials with the hollow interior by galvanic replacement and their enhanced catalytic performance has been reported [39,43,51,52]. For example, Song's team fabricated hollow Au@Pt and Au@Pd core-shell nanoparticles by galvanic replacement with Ag cores and applied them in the ethanol oxidation reaction [39]. Guo and colleagues applied Co nanoparticles as sacrificial templates for synthesizing sponge-like Au-Pt core-shell nanomaterials with advantages of high efficiency and low cost [43]. Kuai and co-workers synthesized Au-Pt yolk-shell nanoparticles with ultra-high CO tolerance and enhanced catalytic activities [51]. You and colleagues synthesized Pt-on-Au hollow urchin-like nanoparticles, which present a new structure consisting of a monolayer of small Pt nano-particles (NPs) uniformly overgrown on an Au hollow nanourchin [52]. More recently, Tan and co-workers successfully fabricated hollow Au@Pt NPs with favorable electrochemical performance using a seeded-growth method. This core-shell structure helps to prevent agglomeration, and can better maintain long-term stability to MOR by effectively removing intermediates [53].

Here, we report an easy and low-cost method for synthesizing Pt nanocluster-anchored hollow $\mathrm{Ag}-\mathrm{Au}$ nanostructures. The final nanostructures can be gained by a three-step successive process: (1) synthesis of uniform $\mathrm{Ag}$ nanospheres by reduction of $\mathrm{AgNO}_{3}$, (2) preparation of hollow $\mathrm{Ag}-\mathrm{Au}$ nanostructures by galvanic replacement of the as-prepared $\mathrm{Ag}$ nanospheres with $\mathrm{Au}^{3+}$, and (3) deposition of Pt nanoclusters on hollow Ag-Au nanostructures by reduction of $\mathrm{K}_{2} \mathrm{PtCl}_{4}$ with ascorbic acid. The morphological, optical, crystallographic, compositional, and electrocatalytic information of resultant products were measured and collected by transmission electron microscopy (TEM), ultraviolet-visible spectroscopy (UV-vis), X-ray diffraction analysis (XRD), inductively coupled plasma mass spectrometry (ICP-MS), and cyclic voltametric (CV) measurements. The synthetic strategy applied in this report is simple and can be extended for preparing more complex bimetallic or multimetallic nanostructures. In addition, the good electrochemical catalytic performance of the nanostructures reveals the possibility of their application in DMFCs. 


\section{Results and Discussion}

\subsection{Physical and Chemical Characterizations}

Scheme 1 displays a general synthetic approach to fabricating Pt nanocluster-anchored hollow Ag-Au nanostructures. As illustrated, the whole procedure begins with the synthesis of uniform Ag nanospheres. The prepared Ag nanospheres are used as the sacrificial template in the preparation of hollow Ag-Au nanostructures. Finally, Pt nanoclusters are generated on the surface of hollow Ag-Au nanostructures by reducing $\mathrm{K}_{2} \mathrm{PtCl}_{4}$ with $\mathrm{L}(+)$-ascorbic acid in an aqueous solution containing (cetyltrimethylammonium bromide) CTAB.

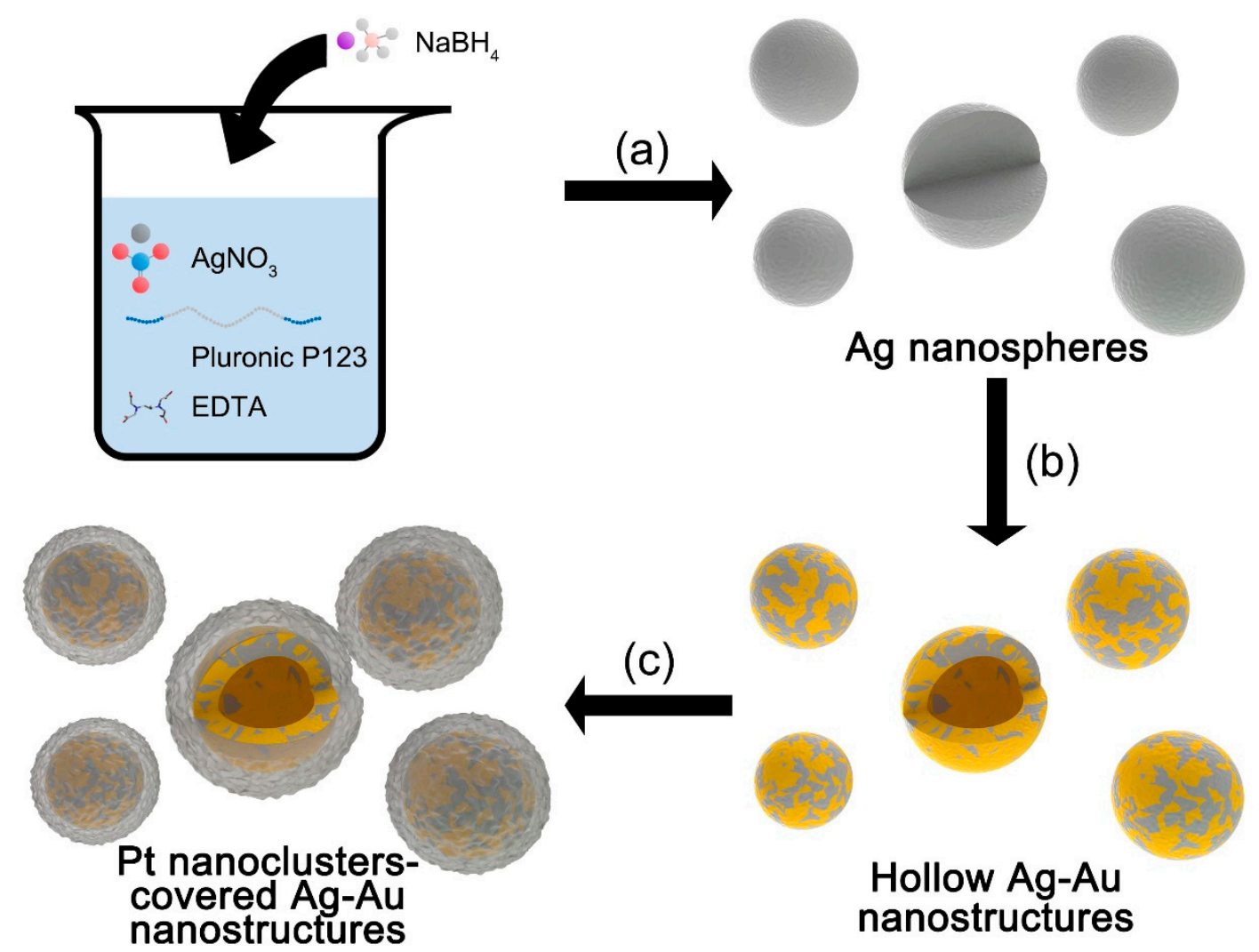

Scheme 1. Schematic illustration of a successive procedure for preparing Pt nanocluster-anchored hollow Ag-Au nanostructures: (a) starting synthesis of uniform Ag nanospheres by adding $\mathrm{NaBH}_{4}$ solution into the mixed aqueous solution of $\mathrm{AgNO}_{3}$, EDTA and Pluronic P123, (b) transforming Ag nanospheres into hollow Ag-Au nanostructures by injecting $\mathrm{HAuCl}_{4}$ solution and (c) coating $\mathrm{Pt}$ nanoclusters on the surface of hollow Ag-Au nanostructures.

It should be noted that Pluronic P123 [54,55] was used as a capping agent to stabilize Ag nanocrystals which appear at an early stage in the synthesis of Ag nanospheres. In addition, EDTA was used for slowing down the reduction speed of $\mathrm{AgNO}_{3}$ because it possesses hexadentate ligand and chelate function group which can form a complex with $\mathrm{Ag}^{+}$[56]. Accordingly, Ag nanospheres with narrow size distribution and good stability were successfully prepared. Figure 1a,b displays typical TEM images of the as-prepared Ag nanospheres with an average diameter of $7.4 \pm 1.2 \mathrm{~nm}$ (Figure S1a). 

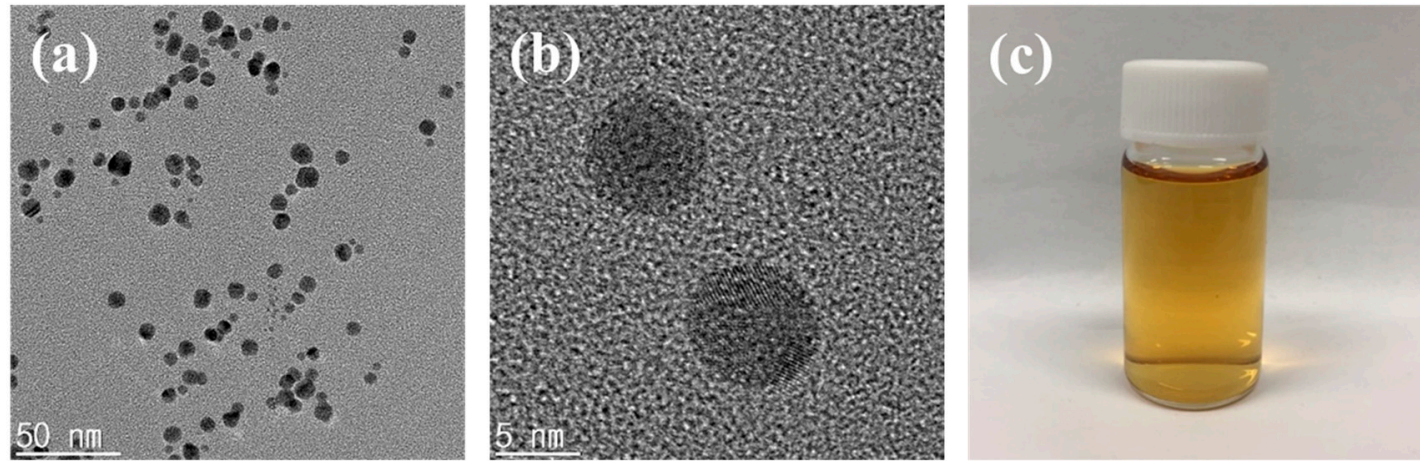

Figure 1. TEM image (a) and HR-TEM image (b) of Ag nanospheres and (c) digital photograph of the resultant solution of Ag nanospheres.

Afterwards, the transformation of Ag nanospheres into hollow Ag-Au nanostructures was achieved by galvanic replacement with gold ions. Referring to the involved reaction mechanism, $\left[\mathrm{AuCl}_{4}\right]^{-}$ions were supposed to adjoin to the surface of $\mathrm{Ag}$ nanospheres, then the exchange of electrons happened immediately. With the reaction went on, Ag was replaced by Au from surface to interior of Ag nanospheres $[40,49,57,58]$. Based on the mechanism, proper reaction kinetics would be a critical factor in the formation of hollow Ag-Au nanostructures. Thus, continuous and slow injection of the $\mathrm{HAuCl}_{4}$ solution by syringe pump was adopted to ensure appropriate reaction speed, $\mathrm{Ag}$ has time to completely dissolve from certain sites, leaving Au particles on the Au surface, forming a hollow $\mathrm{Ag}-\mathrm{Au}$ nanostructure [59]. The hollow interior of the obtained Ag-Au nanostructures with an average diameter of $11.4 \pm 1.4 \mathrm{~nm}$ could be observed through TEM measurements (Figure 2a,b) and size distribution analysis.
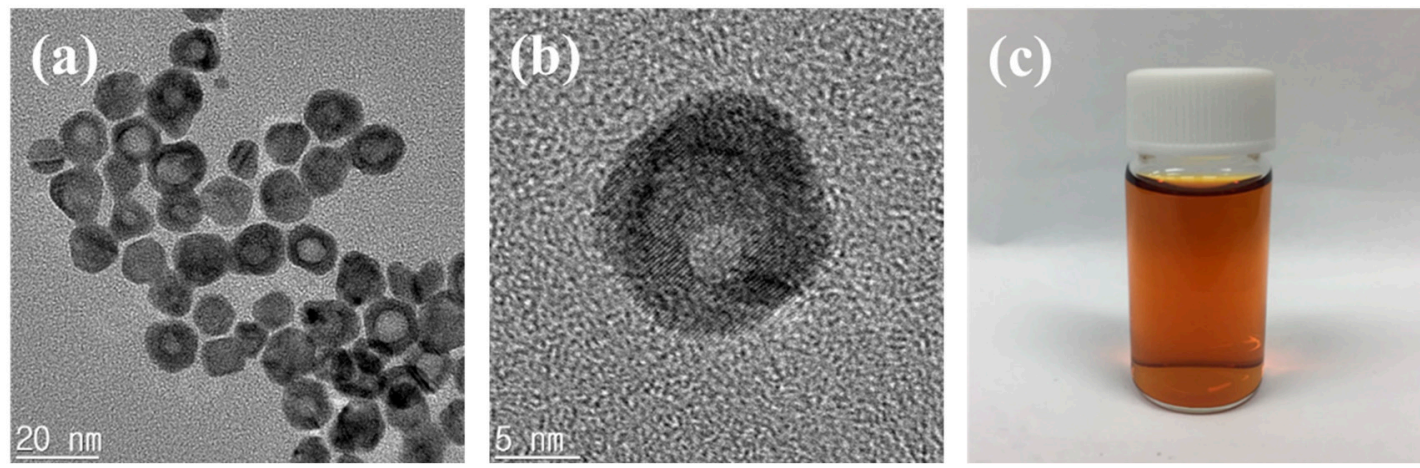

Figure 2. TEM image (a) and HR-TEM image (b) of hollow Ag-Au nanostructures and (c) digital photograph of resultant solution of hollow Ag-Au nanostructures.

Finally, deposition of $\mathrm{Pt}$ on hollow $\mathrm{Ag}$-Au nanostructures was made by reduction of $\mathrm{K}_{2} \mathrm{PtCl}_{4}$ with $\mathrm{L}(+)$-ascorbic acid in an aqueous solution of CTAB. The injected molar ratio of $\mathrm{Pt} / \mathrm{Au}$ in our study was set from 1 to 3 . Figure $3 \mathrm{a}-\mathrm{c}$ shows TEM images of the Pt nanocluster-anchored $\mathrm{Ag}-\mathrm{Au}$ hollow nanostructures at different molar ratios of Pt/Au. As HR-TEM images shown in Figure $3 d-f$, the obtained nanostructures exhibited rough surface due to sporadic Pt deposition on the surface of hollow Ag-Au nanostructures. With the injected $\mathrm{Pt} / \mathrm{Au}$ molar ratio increasing, the average diameter of final products displayed narrow size distribution and varied from $10.4 \pm 0.9 \mathrm{~nm}$ to $12.4 \pm 1.4 \mathrm{~nm}$. We can observe the enlargement of the particle size and the surface roughness under the same magnification. When the surface changes from flat to very wrinkled, the surface area and exposure of edge atom also increases, which can bring many benefits to the catalytic activity. Moreover, the HAADF-STEM images (Figure 3g-i) of the nanostructures showed the relative position of the elements, namely the bright portion suggests a high portion of the elements and vice versa. In detail, the lightness of the 
bright portion in Figure $3 \mathrm{i}$ is higher than that in Figure $3 \mathrm{~g}, \mathrm{~h}$, meaning more concentrated Pt element is anchored on the sample showed in Figure 3i. On the other hand, an obvious contrast between the bright and dark portion in Figure $3 \mathrm{~g}-\mathrm{i}$ proved that hollow structure is uniformly synthesized. Therefore, the hollow interiors of the as-obtained nanostructures could be observed clearly.
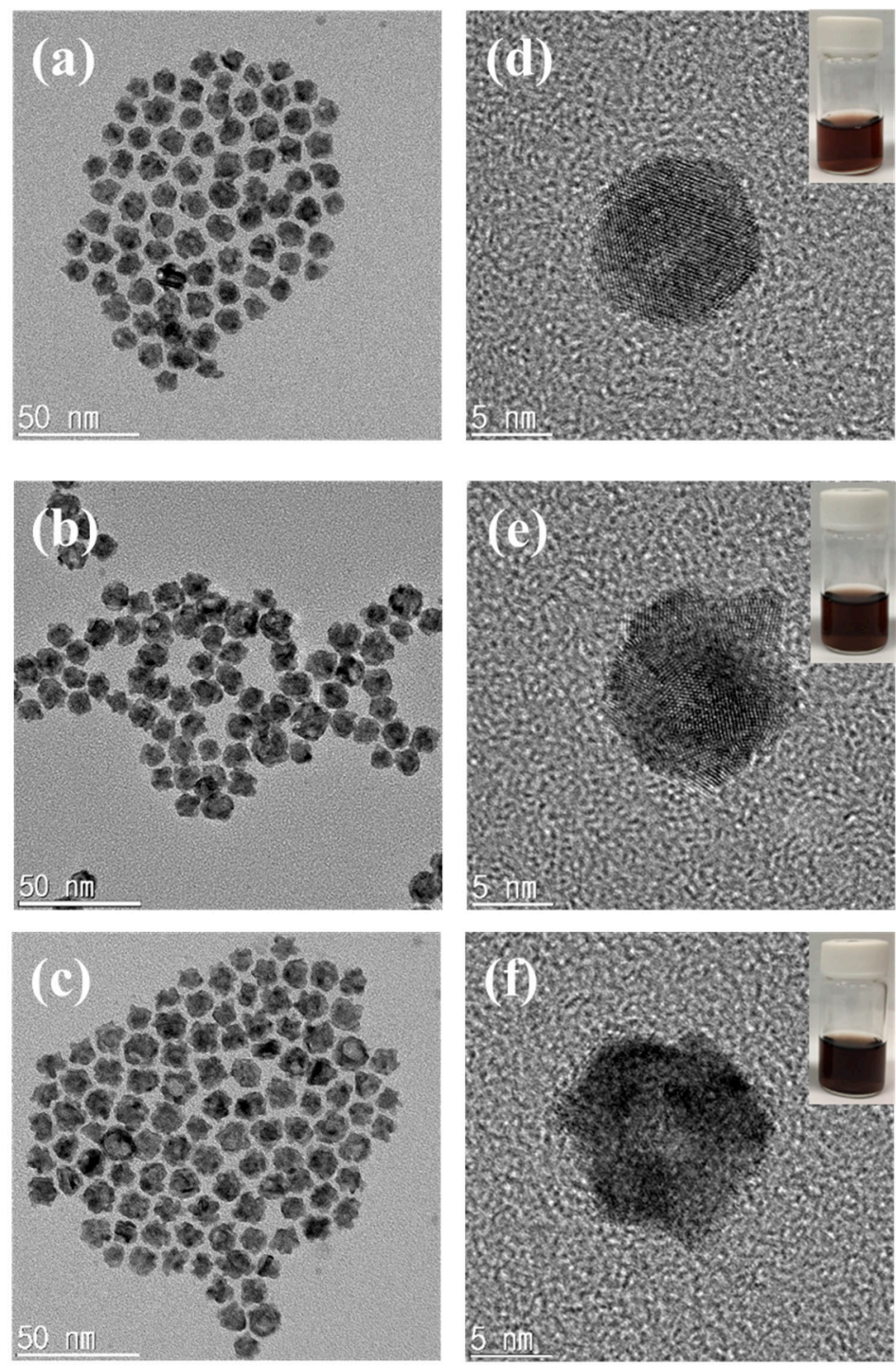
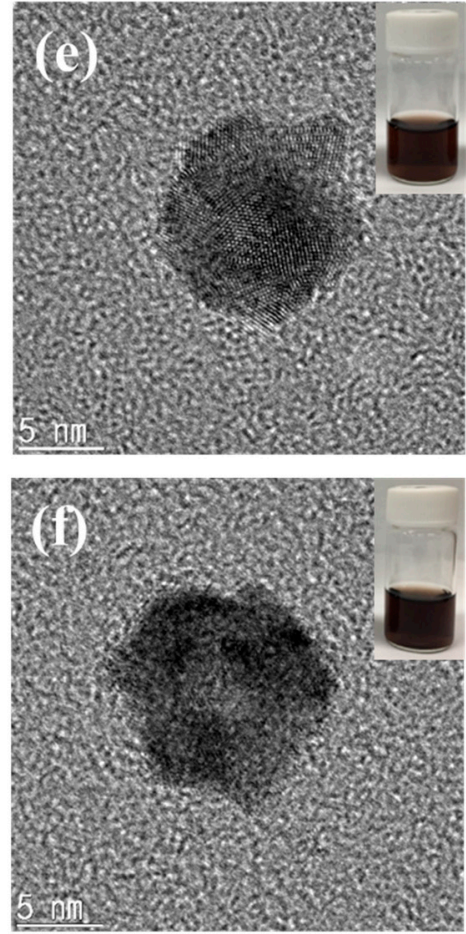
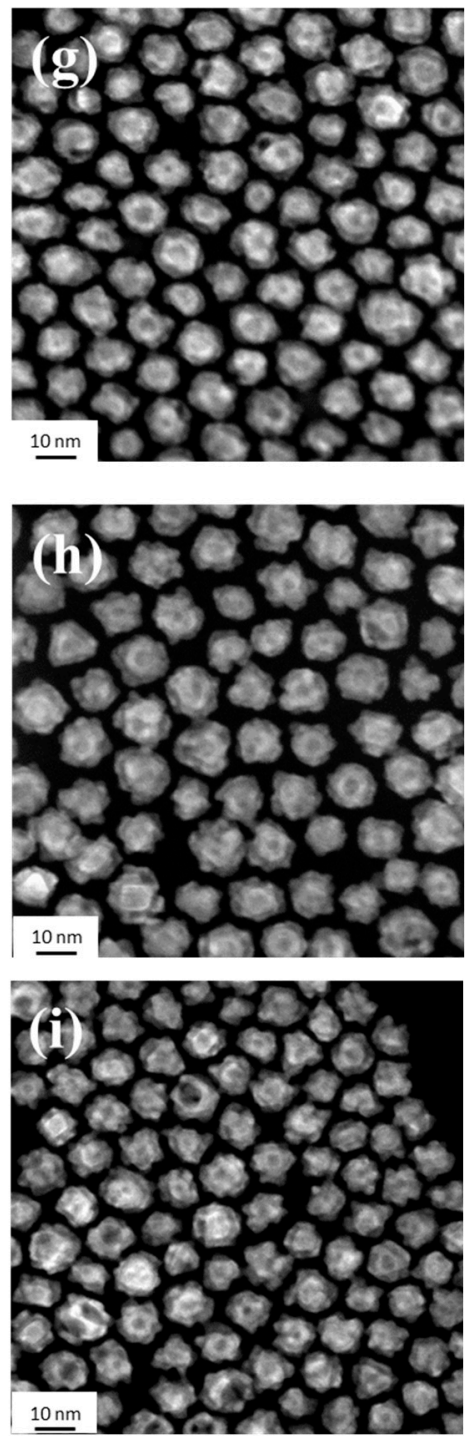

Figure 3. TEM images (a-c), HR-TEM images (d-f), and HAADF-STEM images (g-i) of Pt nanocluster-anchored hollow $\mathrm{Ag}-\mathrm{Au}$ nanostructures with an injected molar ratio of $\mathrm{Pt} / \mathrm{Au}$ from 1 to 3 . The inset pictures in HR-TEM images are digital photographs of resultant solution of the obtained nanostructures.

Then, compositional information of all the as-prepared Pt nanocluster-anchored hollow Ag-Au nanostructures was collected by ICP-MS analysis (Table 1). From Table 1, when comparing the actual amount of Pt to theoretical counterpart, considerable Pt loss in the products could be observed obviously, which range from $39.47 \%$ to $46.24 \%$. The analysis result also confirmed existence of unreplaced Ag content in the resultant nanostructures, which indicating the incomplete galvanic replacement of $\mathrm{Ag}$ nanospheres. Additionally, as for the $\mathrm{Pt} / \mathrm{Au}$ molar ratio of our products, the results were linearly dependent to the value of the injected molar ratio (Figure 4), which were calculated as $0.87,1.74$ and 2.26. Moreover, energy-dispersive X-ray (EDX) analysis was performed for further understanding of component information of the nanostructures (Figures S2-S4). 


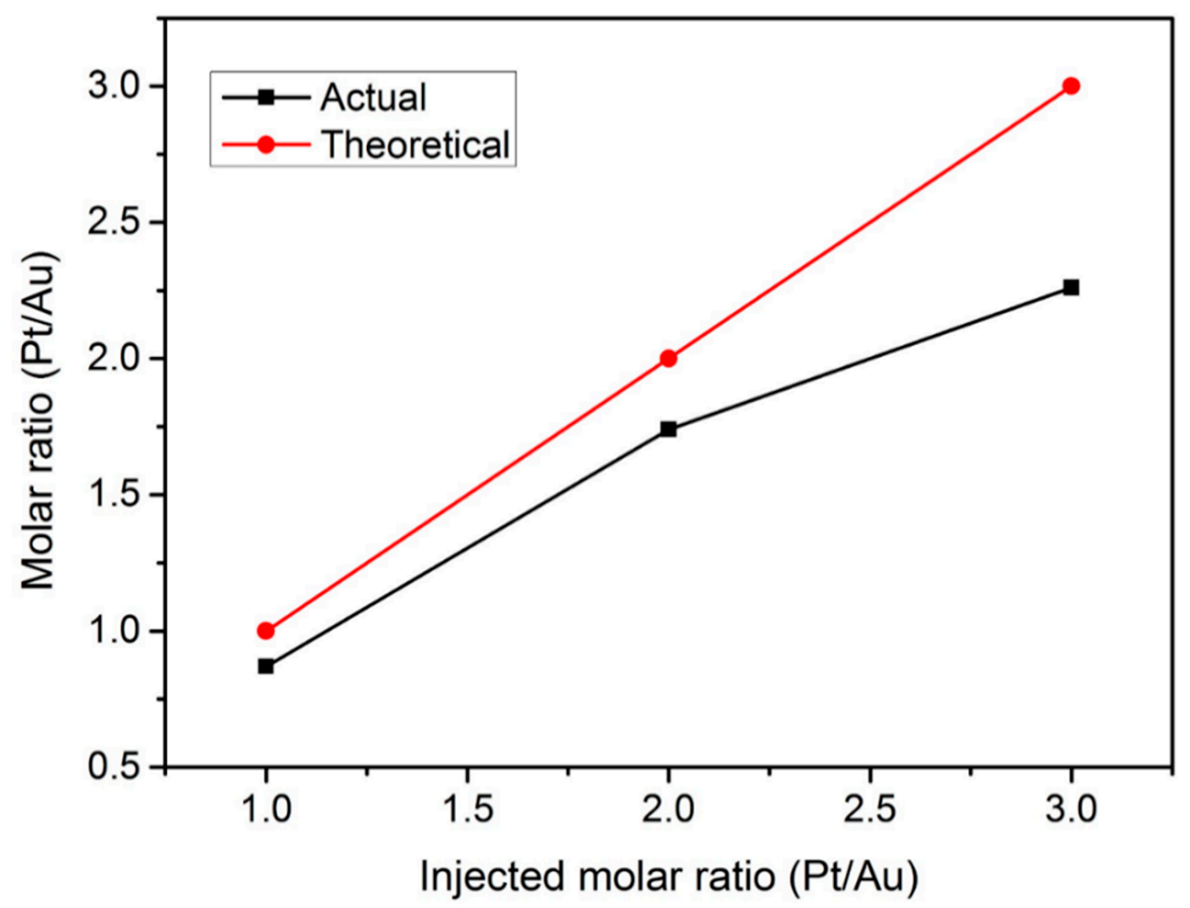

Figure 4. Plots of the $\mathrm{Pt} / \mathrm{Au}$ molar ratio of $\mathrm{Pt}$ nanocluster-anchored hollow Ag-Au nanostructures at actual value (black line) and theoretical value (red line) against the injected $\mathrm{Pt} / \mathrm{Au}$ molar ratio.

Table 1. Compositional information of Pt nanocluster-anchored hollow Ag-Au nanostructures with injected molar ratios of Pt/Au from 1 to 3 confirmed by ICP-MS.

\begin{tabular}{|c|c|c|c|}
\hline & Sample 1 & Sample 2 & Sample 3 \\
\hline $\mathrm{Ag} / \mathrm{ppb}(\%)$ & $1376.3(13.68)$ & $1598.9(11.42)$ & $1769.0(10.26)$ \\
\hline $\mathrm{Au} / \mathrm{ppb}(\%)$ & $4666.9(46.40)$ & $4569.9(32.62)$ & $4782.5(27.73)$ \\
\hline $\mathrm{Pt} / \mathrm{ppb}(\%)$ & $4015.0(39.92)$ & $7839.9(55.96)$ & $10,696.4(62.01)$ \\
\hline Molar ratio $(\mathrm{Pt} / \mathrm{Au})$ & 0.87 & 1.74 & 2.26 \\
\hline Theoretical Pt mass/ $\mu \mathrm{g}$ & 66.33 & 132.66 & 198.98 \\
\hline 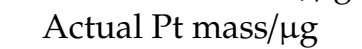 & 40.15 & 78.40 & 106.96 \\
\hline Pt loss (\%) & 39.47 & 40.90 & 46.24 \\
\hline
\end{tabular}

Afterwards, the UV-vis spectra (Figure 5) of Ag nanospheres, Ag-Au nanostructures, and $\mathrm{Pt}$ nanocluster-anchored hollow Ag-Au nanostructures were collected. A narrow absorption peak at $397 \mathrm{~nm}$ caused by the surface plasmon resonance of Ag nanospheres could be observed in Figure 5 . As for hollow Ag-Au nanostructures, the spectra display relatively broader absorption peak than that of Ag nanospheres at a wavelength of about $427 \mathrm{~nm}$. In the case of Pt nanocluster-anchored hollow Ag-Au nanostructures, the suppression and disappearance of the absorption peak at the wavelength that could initially be observed from Au-Ag nanostructures as the molar ratio of $\mathrm{Pt} / \mathrm{Au}$ increased, since the deposition of Pt on the surface of Ag-Au nanostructures. Specifically, a red shift of absorption peak happened when the molar ratio of $\mathrm{Pt} / \mathrm{Au}$ equals 1 and further suppression of the absorption peak could be seen obviously for the nanocomposite with $\mathrm{Pt} / \mathrm{Au}$ molar ratio of 2 . When the molar ratio of $\mathrm{Pt} / \mathrm{Au}$ reaches 3, a more stable $\mathrm{Pt}$ shell has been fabricated, the absorption peak vanished and be substituted by a downslope absorption curve [60]. 


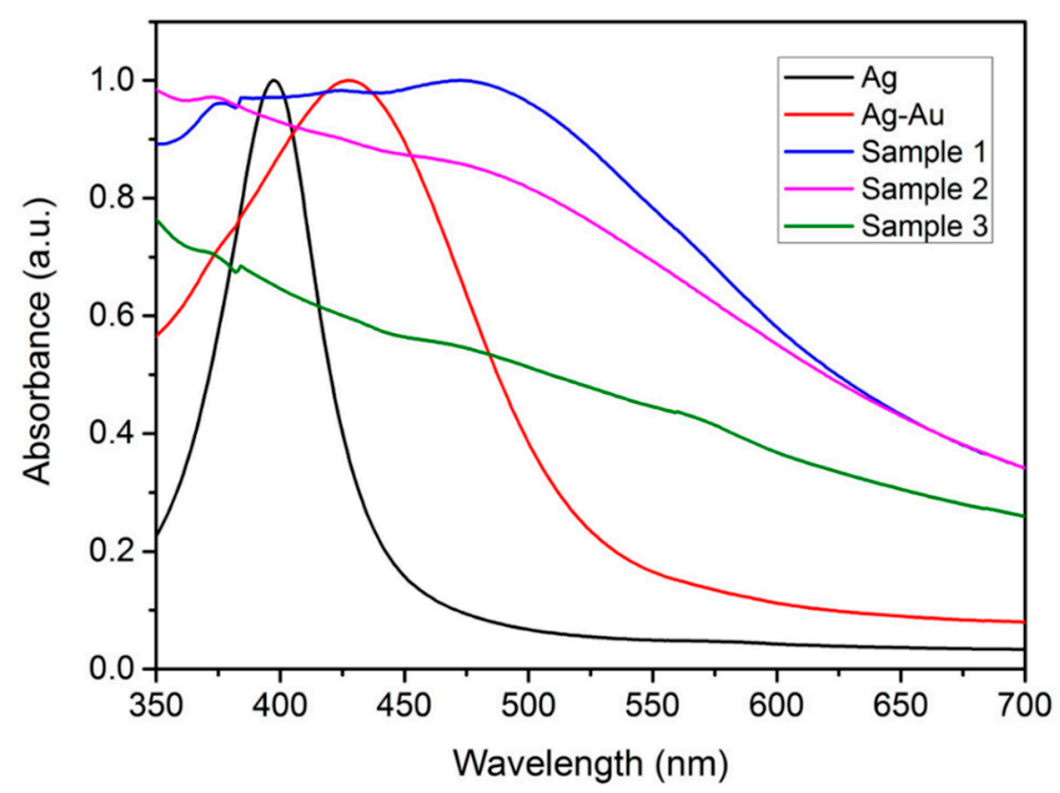

Figure 5. Normalized UV-vis spectra of Ag nanospheres (black line), hollow Ag-Au nanostructures (red line), and Pt nanocluster-anchored hollow Ag-Au nanostructures with injected molar ratios of $\mathrm{Pt} / \mathrm{Au}$ at 1 (blue line), 2 (purple line) and 3 (green line).

XRD patterns of the Pt nanocluster-anchored hollow Ag-Au nanostructures with different $\mathrm{Pt} / \mathrm{Au}$ molar ratio are displayed in Figure 6. When compared to standard diffraction patterns of Ag (JCPDS 65-2871), Au (JCPDS 65-2870) and Pt (JCPDS 65-2868), the overlap of diffraction peaks could be observed from that they are in the range of JCPDS standard diffraction cards. In addition, the diffraction peaks located at 2 theta angles range of $38.24-38.68^{\circ}, 44.64-45.62^{\circ}, 65.32-66.44^{\circ}$ and $78.90-79.56^{\circ}$ are corresponding to (111), (200), (220), and (311) planes of face-centered-cubic (FCC) structure, respectively, which implying alloy structures of the products with different $\mathrm{Pt} / \mathrm{Au}$ molar ratios, in spite low intensity of diffraction peaks of samples.

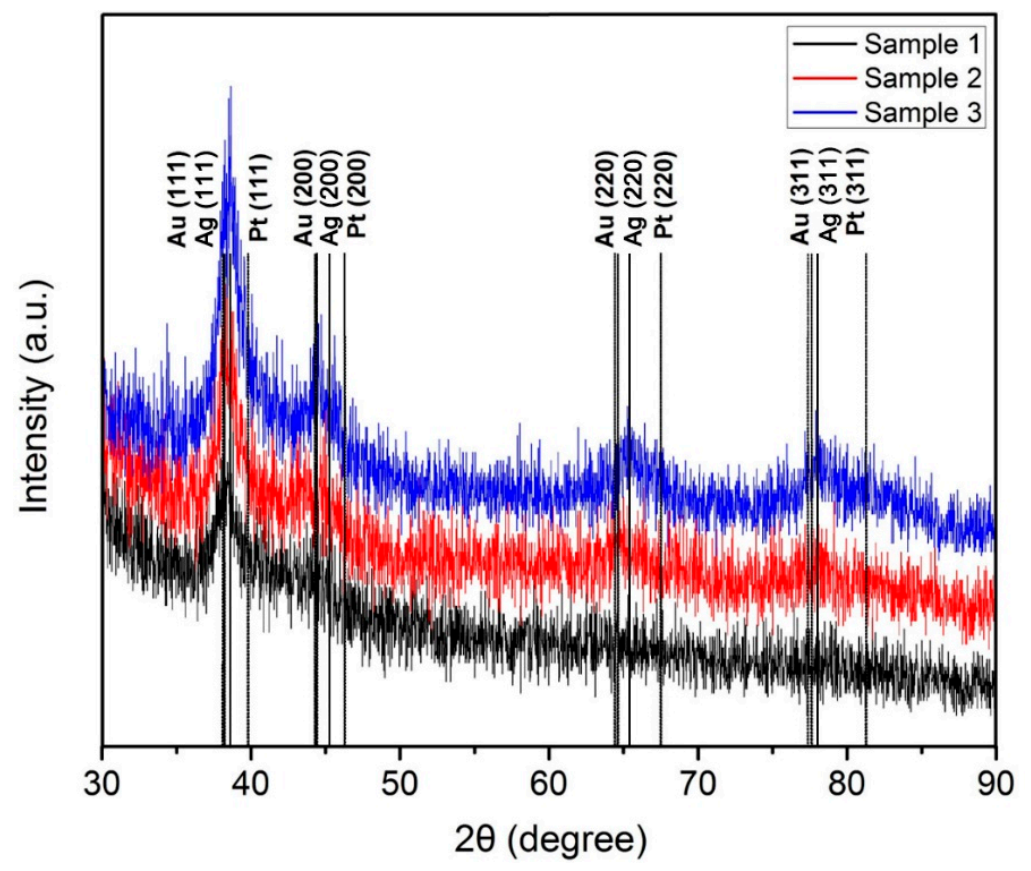

Figure 6. XRD patterns of Pt nanocluster-anchored hollow Ag-Au nanostructures with injected molar ratios of $\mathrm{Pt} / \mathrm{Au}$ at 1 (black line), 2 (red line) and 3 (blue line). 


\subsection{Electrocatalytic Characterization}

$\mathrm{CV}$ measurements of the Pt nanocluster-anchored hollow $\mathrm{Ag}$-Au nanostructures with a different injected molar ratio of $\mathrm{Pt} / \mathrm{Au}$ (1 to 3 ) and commercial $40 \% \mathrm{Pt} / \mathrm{C}$ catalysts were performed in $\mathrm{N}_{2}$-saturated $0.5 \mathrm{M} \mathrm{H}_{2} \mathrm{SO}_{4}+1.0 \mathrm{M} \mathrm{CH}_{3} \mathrm{OH}$ solution at room temperature. The $\mathrm{CV}$ results were displayed in Figure $7 \mathrm{a}$ and the current was normalized by the Pt loading. From Figure 7a, forward and backward current peaks, which correspond to the oxidation of methanol and formation of intermediate products respectively [19], can be observed clearly in CV curves of all catalysts so that confirming their electrocatalytic activity for MOR. Therefore, the current intensity of forward sweep in CV curves of MOR could be assumed as an indicator of the magnitude of electrocatalytic properties of catalysts [11]. Specifically, in the case of the Pt nanocluster-anchored hollow Ag-Au nanostructures with a different molar ratio of $\mathrm{Pt} / \mathrm{Au}$, the $\mathrm{CV}$ curves displayed higher mass activity with the amount of $\mathrm{Pt}$ loading increased to a certain level. When the molar ratio of $\mathrm{Pt} / \mathrm{Au}$ are 1 and 2, the mass activity of correspondents reached $57.2 \mathrm{~mA} \cdot \mathrm{mg}^{-1}$ and $86.5 \mathrm{~mA} \cdot \mathrm{mg}^{-1}$, respectively. As for the Pt nanocluster-anchored hollow Ag-Au nanostructures with a molar ratio of $\mathrm{Pt} / \mathrm{Au}$ equals 3, the mass activity soared to $323.1 \mathrm{~mA} \cdot \mathrm{mg}^{-1}$. Additionally, commercial $40 \% \mathrm{Pt} / \mathrm{C}$ catalyst was used for the sake of comparison in our study and it displayed a mass activity reached up to $259.3 \mathrm{~mA} \cdot \mathrm{mg}^{-1}$, which was lower than that of the hollow nanostructure at $\mathrm{Pt} / \mathrm{Au}$ molar ratio of 3 . However, when further increase the thickness of Pt layer on Ag-Au core by lifting the $\mathrm{Pt} / \mathrm{Au}$ molar ratio to 4 (identified as Sample 4), the activity of which has greatly decreased, as shown in Figure S5. Furthermore, the small size of the as-synthesized uniformly crystallized nanostructures is believed to offers greater surface area and more exposure of catalytic sites of $\mathrm{Pt}$, which accelerates the MOR process [33,61]. This phenomenon was reasonable: Owing to the high surface-to-volume-ratios, elevated use of $\mathrm{Pt}$ and abundant active sites, our catalyst exhibits high activity toward the MOR. Taken together, better durability with thicker layer could be attributed to more generation of $\mathrm{Pt}$ stable phase toward MOR [62-64]. The results also displayed the immense potential of as-prepared Pt nanocluster-anchored hollow Ag-Au nanostructures as efficient Pt-based catalysts in applications of DMFCs. The long-term stability of the Pt nanocluster-anchored hollow $\mathrm{Ag}-\mathrm{Au}$ nanostructures (injected molar ratio of $\mathrm{Pt} / \mathrm{Au}, 3: 1$ ) and commercial $40 \% \mathrm{Pt} / \mathrm{C}$ catalysts was evaluated by chronoamperometric measurement under a constant potential of $0.70 \mathrm{~V}$ for $5000 \mathrm{~s}$ as shown in Figure $7 b$, which is used to determine the effect of carbon monoxide adsorption during methanol oxidation. Pt nanocluster-anchored hollow Ag-Au nanostructures produced an initial specific activity of $193.3 \mathrm{~mA} \cdot \mathrm{mg}^{-1}$ and a final specific activity of $79.2 \mathrm{~mA} \cdot \mathrm{mg}^{-1}$, corresponding to $40.97 \%$ of the initial response. Commercial $40 \% \mathrm{Pt} / \mathrm{C}$ produced an initial specific activity of $153.9 \mathrm{~mA} \cdot \mathrm{mg}^{-1}$ and a final specific activity of $62.4 \mathrm{~mA} \cdot \mathrm{mg}^{-1}$, corresponding to $40.54 \%$ of the initial response. The polarization currents decrease rapidly at the initial stage, which is due to the formation of intermediate species during MOR [65,66]. In this manner, Pt nanocluster-anchored hollow Ag-Au nanostructures maintained a specific activity $0.43 \%$ greater than commercial $40 \% \mathrm{Pt} / \mathrm{C}$ for the oxidation of methanol during chronoamperometry, which further reveals the high electrochemical durability of the as-prepared nanostructure.

For a more comprehensively understanding of the electrocatalytic performance, $\mathrm{CV}$ measurement of the Pt nanocluster-anchored hollow Ag-Au nanostructures with a different injected molar ratio of $\mathrm{Pt} / \mathrm{Au}$ (1 to 3) were evaluated. Commercial $40 \% \mathrm{Pt} / \mathrm{C}$ catalyst was selected as a reference catalyst. $\mathrm{CV}$ curves were performed in $\mathrm{N}_{2}$-saturated $0.5 \mathrm{M} \mathrm{H}_{2} \mathrm{SO}_{4}$ solution at room temperature (Figure 8a). The electrochemical active surface areas (ECSA) of the as-prepared hollow nanostructure and the commercial catalyst were calculated to be 9.85 (Sample 1), 10.42 (Sample 2), 19.32 (Sample 3) and 18.02 $(40 \% \mathrm{Pt} / \mathrm{C}) \mathrm{m}^{2} \cdot \mathrm{g}^{-1}$, respectively (Table S1) by hydrogen desorption peak zone between -0.2 to $0.2 \mathrm{~V}$ vs. $\mathrm{Ag} / \mathrm{AgCl}$ electrode. Additionally, several indicators of catalytic performance, including Pt loading, specific activity, mass activity, ECSA, and peak potential of testing samples, were listed in Figure 8b and Table S1. Uniform products with hollow nanostructures may be responsible for (electrochemical surface area) ESCA value and offer many active sites, indicating the better electrocatalytic performance. 

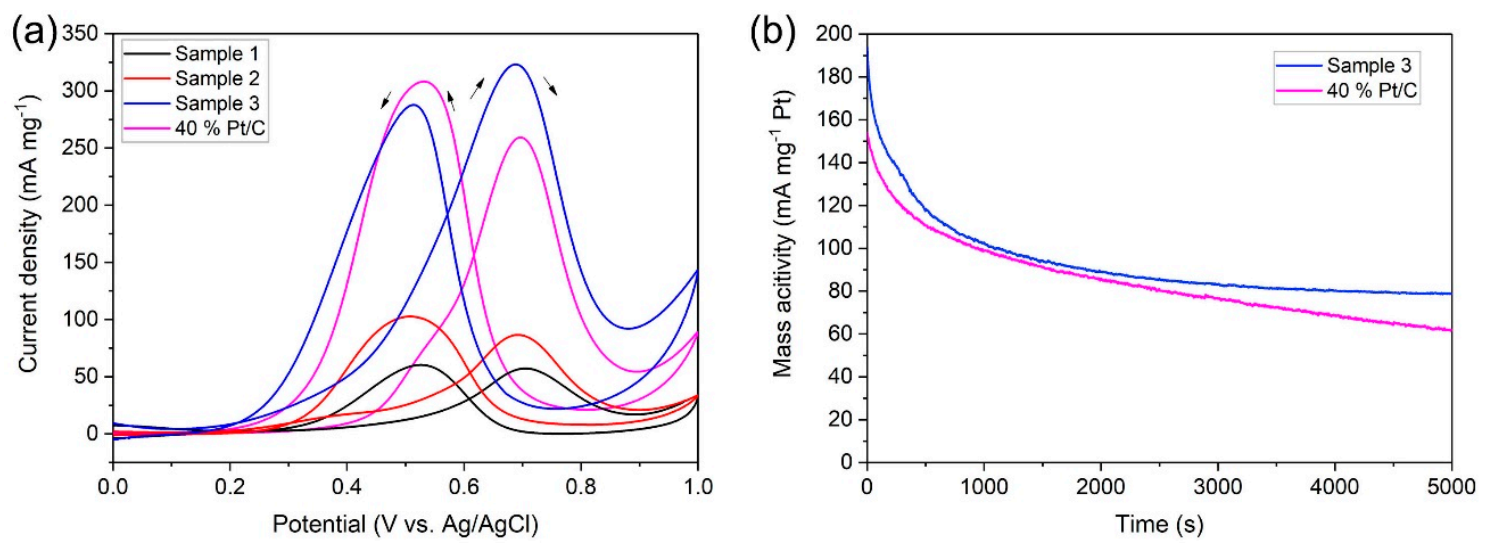

Figure 7. (a) CV curves of Pt nanocluster-anchored hollow Ag-Au nanostructures with injected molar ratios of $\mathrm{Pt} / \mathrm{Au}$ at 1 (black line), 2 (red line) 3 (blue line) and commercialized $40 \% \mathrm{Pt} / \mathrm{C}$ catalysts (purple lien) recorded in $\mathrm{N}_{2}$-saturated $1 \mathrm{M} \mathrm{CH}_{3} \mathrm{OH}+0.5 \mathrm{M} \mathrm{H}_{2} \mathrm{SO}_{4}$ solution. (b) Chronoamperometric curves of $\mathrm{Pt} / \mathrm{Au}$ at 3 (blue line) and commercialized $40 \% \mathrm{Pt} / \mathrm{C}$ catalysts (purple lien) recorded at $0.70 \mathrm{~V}$ (vs. $\mathrm{Ag} / \mathrm{AgCl}$ ) in $\mathrm{N}_{2}$-saturated $1 \mathrm{M} \mathrm{CH}_{3} \mathrm{OH}+0.5 \mathrm{M} \mathrm{H}_{2} \mathrm{SO}_{4}$ solution.
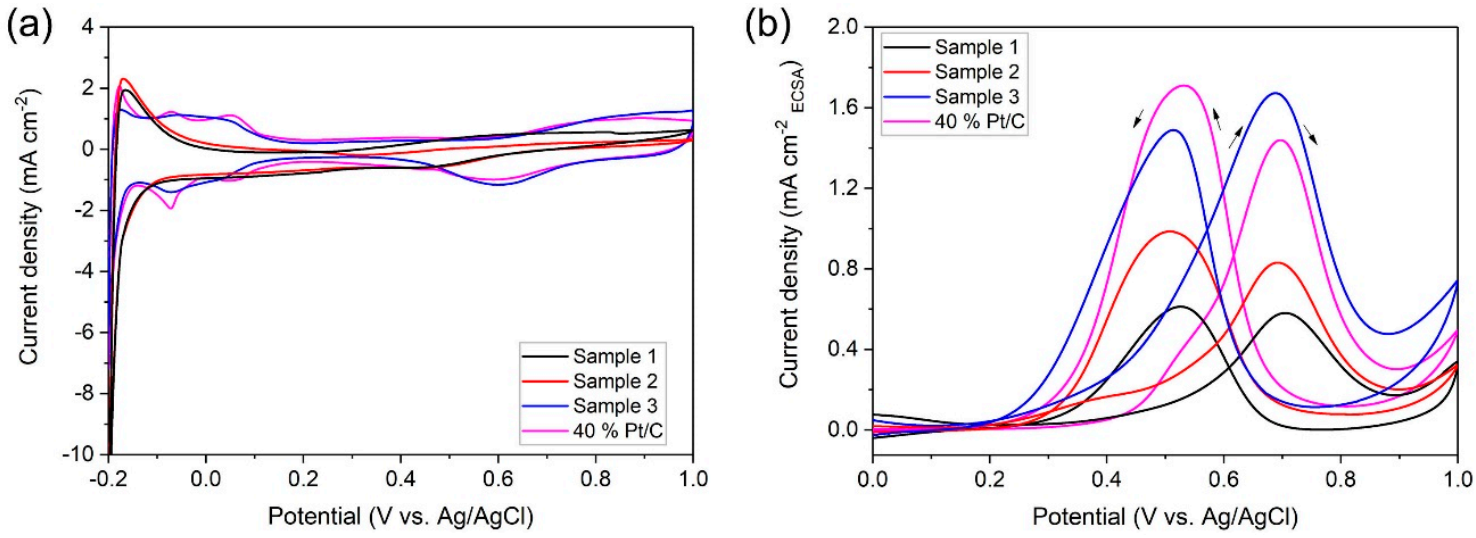

Figure 8. (a) CV curves of Pt nanocluster-anchored hollow Ag-Au nanostructures with injected molar ratios of $\mathrm{Pt} / \mathrm{Au}$ at 3 (black line) and commercialized $40 \% \mathrm{Pt} / \mathrm{C}$ catalysts (red line) recorded in $\mathrm{N}_{2}$-saturated 0.5 $\mathrm{M} \mathrm{H}_{2} \mathrm{SO}_{4}$ solution. (b) Electrocatalytic performance of Pt nanocluster-anchored hollow $\mathrm{Ag}-\mathrm{Au}$ nanostructures with injected molar ratios of $\mathrm{Pt} / \mathrm{Au}$ at 1 (black line), 2 (red line) 3 (blue line) and commercialized $40 \% \mathrm{Pt} / \mathrm{C}$ catalysts (purple lien) recorded in $\mathrm{N}_{2}$-saturated $1 \mathrm{M} \mathrm{CH}_{3} \mathrm{OH}+0.5 \mathrm{M}$ $\mathrm{H}_{2} \mathrm{SO}_{4}$ solution.

However, when compared to the theoretical amount of Pt from the testing result of ICP-MS analysis, it could be observed that a considerable amount of Pt loss occurred during centrifugation processes for washing the resultant products (Table S2). Moreover, due to the strong attachment of CTAB onto the surface of the Pt nanocluster-anchored hollow Ag-Au nanostructures and the electrocatalytic activity intensively relies on the accessibility of catalysts to the electrolyte, it could be inferred that the appropriate extent of centrifugation, neither be inadequate for removing CTAB nor so excessive that leading to aggregation of nanocomposites, was another key factor which influences the catalytic performance of the obtained catalysts for MOR. Therefore, further exploration of efficient and proper washing method with lower Pt loss would be needed for practical application of Pt-anchored hollow Ag-Au nanostructures in MOR and DMFCs. 


\section{Materials and Methods}

\subsection{Materials}

$\mathrm{AgNO}_{3}, \mathrm{NaBH}_{4}$, sulfuric acid $\left(\mathrm{H}_{2} \mathrm{SO}_{4}\right)$, methanol $\left(\mathrm{CH}_{3} \mathrm{OH}\right)$ were purchased from Samchun Pure Chemical Corp. Nafion perfluorinated resin solution (5 wt.\% in lower aliphatic alcohols and water, contains $15-20 \%$ water), $\mathrm{K}_{2} \mathrm{PtCl}_{4}$, gold (III) chloride trihydrate $\left(\mathrm{HAuCl}_{4} \cdot 3 \mathrm{H}_{2} \mathrm{O}\right), \mathrm{L}(+)$-ascorbic acid, ethylenediaminetetraacetic acid (EDTA) and hexadecyltrimethylammonium bromide (CTAB) were purchased from Sigma-Aldrich Chemical Corp. Pluronic P123 (Poly (ethylene glycol)-block-poly (propylene glycol)-block-poly (ethylene glycol)) was purchased from BASF Corp. Commercial 40\% $\mathrm{Pt} / \mathrm{C}$ catalyst ( $\mathrm{y}$ are located in the range of JCPDS standard diffraction cards. In addition, the diffraction peaks located at 2 theta angles range of $38.24-38.68^{\circ}, 44.64-45.62^{\circ}, 65.32-66.44^{\circ}$ and $78.90-79.56^{\circ}$ are corresponding to (111), (200), (220), and (311) planes of FCC structure, respectively, which implying alloy structures of the products with different $\mathrm{Pt} / \mathrm{Au}$ molar ratios, in spite low intensity of diffraction peaks of samples.

\subsection{Synthesis of Uniform Ag Nanospheres}

Synthesis of uniform Ag nanospheres could be described as follows. A mixture of $0.1 \mathrm{~mL}$ of $0.1 \mathrm{M} \mathrm{AgNO}_{3}$ solution with $0.1 \mathrm{~mL}$ of $1 \mathrm{M}$ EDTA solution was added into $9 \mathrm{~mL}$ of $0.2 \mathrm{~g}$ Pluronic P123 homogeneous aqueous solution, then the blended solution was stirred for $0.5 \mathrm{~h}$ at room temperature. Afterwards, $0.6 \mathrm{~mL}$ of $0.3 \mathrm{M}$ freshly made ice-cold $\mathrm{NaBH}_{4}$ solution was added into the mixed solution quickly to initiate the reaction and vigorous stirring was sustained for daylong time to complete the synthesis of $\mathrm{Ag}$ nanospheres. After the addition of $\mathrm{NaBH}_{4}$ solution, immediate color change of the solution, from transparent into blackish green and light yellow eventually, could be observed.

\subsection{Synthesis of Hollow Ag-Au Nanostructures}

In the synthesis of hollow $\mathrm{Ag}$-Au nanostructures via galvanic replacement, the as-prepared $\mathrm{Ag}$ nanospheres were served as sacrificial materials to react with $\mathrm{HAuCl}_{4}$. Specifically, $2 \mathrm{~mL}$ of $3.4 \times 10^{-4} \mathrm{M}$ $\mathrm{HAuCl}_{4}$ solution was injected into $2 \mathrm{~mL}$ of $\mathrm{Ag}$ nanosphere solution by a syringe pump at an injection rate of $1 \mathrm{~mL} / \mathrm{h}$ with vigorous stirring for $6 \mathrm{~h}$. With continuous injection went on, the color of the solution was changed from light yellow to orange-yellow eventually.

\subsection{Synthesis of Pt Nanocluster-Anchored Hollow Ag-Au Nanostructures}

Coating of Pt nanoclusters on hollow Ag-Au nanostructures was attained by reduction of $\mathrm{K}_{2} \mathrm{PtCl}_{4}$ with L (+) - ascorbic acid. Specifically, three same samples of each containing $2 \mathrm{~mL}$ of hollow Ag-Au nanostructures solution and $2 \mathrm{~mL}$ of $0.1 \mathrm{M} \mathrm{CTAB}$ solution were prepared first. Then, 34, 68 and $102 \mu \mathrm{L}$ of $0.01 \mathrm{M}$ newly prepared $\mathrm{K}_{2} \mathrm{PtCl}_{4}$ solutions $[67,68]$ were added to the above-mentioned samples, at $\mathrm{Pt} / \mathrm{Au}$ molar ratio which range from 1 to 3. The three samples were labeled as Sample 1, Sample 2, and Sample 3, respectively, and they were left undisturbed for $0.5 \mathrm{~h}$ to complete complexation of CTAB with $\left[\mathrm{PtCl}_{4}\right]^{2-}$. Finally, the addition of 68,136 and $204 \mu \mathrm{L}$ of $0.1 \mathrm{M} \mathrm{L} \mathrm{(+)-ascorbic} \mathrm{acid} \mathrm{solution} \mathrm{to}$ each sample was followed with vigorous stirring for $36 \mathrm{~h}$ to complete the reaction. The resultant solution which displayed color of dark brown was centrifuged for 3 times $(12,000 \mathrm{rpm}, 30 \mathrm{~min})$ and the precipitate was redispersed in $0.5 \mathrm{~mL}$ DI water for further characterizations (TEM and ICP-MS).

\subsection{Physical and Chemical Characterizations}

TEM and HR-TEM images were obtained from JEOL JEM-2100F transmission electron microscope equipped with EDX spectroscopy detector and Cs corrector at accelerating voltage of $200 \mathrm{kV}$. UV-vis spectrum was collected from Perkin-Elmer Lambda 35 UV-vis spectrometer. Information on chemical composition was characterized by Perkin-Elmer SCIEX NexION 350D ICP-mass spectrometer. 
XRD patterns were obtained with a Bruker D8 DISCOVER high-resolution X-ray diffractometer (with $\mathrm{Cu} \mathrm{K} \alpha$ radiation, $\lambda=1.542 \AA$ ).

\subsection{Electrocatalytic Characterization}

$\mathrm{CV}$ measurements were performed with a $\mathrm{CH}$ instrument $660 \mathrm{E}$ electrochemical workstation with three electrodes systems at room temperature. Glassy carbon electrode with $3.0 \mathrm{~mm}$ diameter was used as working electrode. $\mathrm{Ag} / \mathrm{AgCl}$ electrode and $\mathrm{Pt}$ net were selected as a reference and counter electrodes, respectively. In CV measurements, $3 \mu \mathrm{L}$ sample solution was dripped onto the surface of glassy carbon electrode and was dried under an infrared lamp for $10 \mathrm{~min}$. A mixture solution containing $1.0 \mathrm{M}$ $\mathrm{CH}_{3} \mathrm{OH}$ and $0.5 \mathrm{M} \mathrm{H}_{2} \mathrm{SO}_{4}$ was bubbled with $\mathrm{N}_{2}$ gas for 15 min before the measurements. The whole process was conducted under the protection of $\mathrm{N}_{2}$ gas and in a potential range of 0 to $1.0 \mathrm{~V}(\mathrm{vs}$. $\mathrm{Ag} / \mathrm{AgCl})$ at sweep rate of $0.05 \mathrm{~V} / \mathrm{s}$. The MOR stability test was performed in $\mathrm{N}_{2}$-saturated $1 \mathrm{M} \mathrm{CH}_{3} \mathrm{OH}+0.5 \mathrm{M}$ $\mathrm{H}_{2} \mathrm{SO}_{4}$ solution by chronoamperometry at $0.70 \mathrm{~V}$ (vs. $\left.\mathrm{Ag} / \mathrm{AgCl}\right)$.

\section{Conclusions}

In conclusion, $\mathrm{Pt}$ nanocluster-anchored hollow $\mathrm{Ag}-\mathrm{Au}$ nanostructures were synthesized by involving reduction reaction of metal ions $\left(\mathrm{Ag}^{+}, \mathrm{Pt}^{2+}\right)$ and galvanic replacement reaction in aqueous solution $\left(\mathrm{Ag}\right.$ with $\left.\mathrm{Au}^{3+}\right)$. Under optimized conditions, uniform and stable products with hollow nanostructures could be prepared reproducibly. It should be pointed out that involvement of crucial chemicals (Pluronic P123, EDTA, and CTAB) during the synthesis and controlling injection rate of Au stock solution by syringe pump were critical parameters for ensuring stability and uniformity. Owing to the high surface-to-volume-ratios, elevated use of Pt and abundant active sites, hollow structures present a favorable catalytic activity and stability toward MOR. The results of electrochemical measurements showed a higher mass activity and ECSA of the nanostructures than commercial $40 \%$ $\mathrm{Pt} / \mathrm{C}$ catalyst, which indicated the better electrocatalytic performance of them. The experimental results also showed the immense potential of the nanostructures as Pt-based catalysts in the further application for DMFCs. We believe this work may inspire many researchers who work on optimizing and inventing a new type of catalyst with magnificent structures using noble metals. Also, this study can be further extended into other applications such as hydrogen evolution reaction (HER). Moreover, the synthetic approach applied in this study offered a simple and economical way for producing many kinds of complex nanoarchitectures which could find novel applications in various areas.

Supplementary Materials: The following are available online at http://www.mdpi.com/2073-4344/10/12/1440/s1, Figure S1: Size distribution of (a) Ag nanospheres, (b) hollow Ag-Au nanostructures, and (c) Pt nanocluster-anchored hollow Ag-Au nanostructures with injected molar ratio of Pt/Au at 3, Figure S2: EDX spectrum (left) and compositional information (right) of $\mathrm{Pt}$ nanocluster-anchored hollow $\mathrm{Ag}$-Au nanostructures with injected molar ratio of $\mathrm{Pt} / \mathrm{Au}$ at 1, Figure S3: EDX spectrum (left) and compositional information (right) of Pt nanocluster-anchored hollow $\mathrm{Ag}-\mathrm{Au}$ nanostructures with injected molar ratio of $\mathrm{Pt} / \mathrm{Au}$ at 2, Figure S4: EDX spectrum (left) and compositional information (right) of $\mathrm{Pt}$ nanocluster-anchored hollow Ag-Au nanostructures with injected molar ratio of $\mathrm{Pt} / \mathrm{Au}$ at 3 , Figure S5. CV curves of $\mathrm{Pt}$ nanocluster-anchored hollow Ag-Au nanostructures with injected molar ratios of $\mathrm{Pt} / \mathrm{Au}$ at 3 (blue line) and 4 (yellow line) recorded in N2-saturated $1 \mathrm{M} \mathrm{CH} 3 \mathrm{OH}+0.5 \mathrm{M} \mathrm{H} 2 \mathrm{SO} 4$ solution. Table S1: Results of electrochemical measurements of our samples and commercial catalyst for electrochemical oxidation of methanol, Table S2: Pt amount in loading solutions of the nanostructures and commercial catalyst in CV measurements confirmed by ICP-MS.

Author Contributions: Conceptualization, Y.P. and X.L.; methodology, Y.P. and W.Z.; formal analysis, X.L. and X.Q.; investigation, X.L.; data curation, X.L. and X.Q.; writing—original draft preparation, X.L.; writing-review and editing, X.Q., B.Y., and H.H.; supervision, Y.P.; project administration, Y.P.; funding acquisition, Y.P. All authors have read and agreed to the published version of the manuscript.

Funding: This research was supported by the Basic Science Research Program through the National Research Foundation of Korea (NRF) funded by the Ministry of Education (NRF-2018R1D1A1B07051249), Nano Material Technology Development Program (NRF-2015M3A7B6027970) and Science and Technology Amicable Relationships (STAR) Program (NRF-2019K1A3A1A21031052) of MSIT/NRF.

Conflicts of Interest: The authors declare no conflict of interest. 


\section{References}

1. Wasmus, S.; Küver, A. Methanol oxidation and direct methanol fuel cells: A selective review. J. Electroanal. Chem. 1999, 461, 14-31. [CrossRef]

2. Aricò, A.S.; Srinivasan, S.; Antonucci, V. DMFCs: From Fundamental Aspects to Technology Development. Fuel Cells 2001, 1, 133-161. [CrossRef]

3. Li, X.; Faghri, A. Review and advances of direct methanol fuel cells (DMFCs) part I: Design, fabrication, and testing with high concentration methanol solutions. J. Power Sources 2013, 226, 223-240. [CrossRef]

4. Li, Z.; Jiang, X.; Wang, X.; Hu, J.; Liu, Y.; Fu, G.; Tang, Y. Concave PtCo nanocrosses for methanol oxidation reaction. Appl. Catal. B 2020, 277, 119135. [CrossRef]

5. Bonzel, H.P.; Ku, R. Mechanisms of the catalytic carbon monoxide oxidation on Pt (110). Surf. Sci. 1972, 33, 91-106. [CrossRef]

6. Ertl, G.; Neumann, M.; Streit, K.M. Chemisorption of CO on the Pt(111) surface. Surf. Sci. 1977, 64, $393-410$. [CrossRef]

7. Batista, E.A.; Malpass, G.R.P.; Motheo, A.J.; Iwasita, T. New mechanistic aspects of methanol oxidation. J. Electroanal. Chem. 2004, 571, 273-282. [CrossRef]

8. Zhang, Z.; Wang, Y.; Wang, X. Nanoporous bimetallic Pt-Au alloy nanocomposites with superior catalytic activity towards electro-oxidation of methanol and formic acid. Nanoscale 2011, 3, 1663-1674. [CrossRef]

9. Liao, S.; Holmes, K.A.; Tsaprailis, H.; Birss, V.I. High performance PtRuIr catalysts supported on carbon nanotubes for the anodic oxidation of methanol. J. Am. Chem. Soc. 2006, 128, 3504-3505. [CrossRef]

10. Wang, W.; Huang, Q.; Liu, J.; Zou, Z.; Li, Z.; Yang, H. One-step synthesis of carbon-supported Pd-Pt alloy electrocatalysts for methanol tolerant oxygen reduction. Electrochem. Commun. 2008, 10, 1396-1399. [CrossRef]

11. Wang, S.; Kristian, N.; Jiang, S.; Wang, X. Controlled synthesis of dendritic Au@Pt core-shell nanomaterials for use as an effective fuel cell electrocatalyst. Nanotechnology 2009, 20, 25605. [CrossRef] [PubMed]

12. Zhou, Z.; Wang, S.; Zhou, W.; Wang, G.; Jiang, L.; Li, W.; Song, S.; Liu, J.; Sun, G.; Xin, Q. Novel synthesis of highly active $\mathrm{Pt} / \mathrm{C}$ cathode electrocatalyst for direct methanol fuel cell. Chem. Commun. 2003, 394-395. [CrossRef] [PubMed]

13. Luo, J.; Maye, M.M.; Petkov, V.; Kariuki, N.N.; Wang, L.; Njoki, P.; Mott, D.; Lin, Y.; Zhong, C.-J. Phase Properties of Carbon-Supported Gold-Platinum Nanoparticles with Different Bimetallic Compositions. Chem. Mater. 2005, 17, 3086-3091. [CrossRef]

14. Kim, M.; Park, J.-N.; Kim, H.; Song, S.; Lee, W.-H. The preparation of Pt/C catalysts using various carbon materials for the cathode of PEMFC. J. Power Sources 2006, 163, 93-97. [CrossRef]

15. Park, I.-S.; Lee, K.-S.; Jung, D.-S.; Park, H.-Y.; Sung, Y.-E. Electrocatalytic activity of carbon-supported Pt-Au nanoparticles for methanol electro-oxidation. Electrochim. Acta 2007, 52, 5599-5605. [CrossRef]

16. Zhao, D.; Xu, B.Q. Enhancement of Pt utilization in electrocatalysts by using gold nanoparticles. Angezw. Chem. Int. Ed. 2006, 45, 4955-4959. [CrossRef]

17. Luo, J.; Wang, L.; Mott, D.; Njoki, P.N.; Lin, Y.; He, T.; Xu, Z.; Wanjana, B.N.; Lim, I.I.S.; Zhong, C.-J. Core/Shell Nanoparticles as Electrocatalysts for Fuel Cell Reactions. Adv. Mater. 2008, 20, 4342-4347. [CrossRef]

18. Kristian, N.; Wang, X. Ptshell-Aucore/C electrocatalyst with a controlled shell thickness and improved Pt utilization for fuel cell reactions. Electrochem. Commun. 2008, 10, 12-15. [CrossRef]

19. Ataee-Esfahani, H.; Wang, L.; Nemoto, Y.; Yamauchi, Y. Synthesis of Bimetallic Au@Pt Nanoparticles with Au Core and Nanostructured Pt Shell toward Highly Active Electrocatalysts. Chem. Mater. 2010, 22, 6310-6318. [CrossRef]

20. Kim, Y.; Noh, Y.; Lim, E.J.; Lee, S.; Choi, S.M.; Kim, W.B. Star-shaped Pd@Pt core-shell catalysts supported on reduced graphene oxide with superior electrocatalytic performance. J. Mater. Chem. A 2014, 2, 6976-6986. [CrossRef]

21. Xie, R.; Chen, M.; Wang, J.; Mei, S.; Pan, Y.; Gu, H. Facile synthesis of Au-Pt bimetallic nanocomplexes for direct oxidation of methanol and formic acid. RSC Adv. 2015, 5, 650-653. [CrossRef]

22. Ye, H.; Crooks, R.M. Effect of elemental composition of PtPd bimetallic nanoparticles containing an average of 180 atoms on the kinetics of the electrochemical oxygen reduction reaction. J. Am. Chem. Soc. 2007, 129, 3627-3633. [CrossRef] [PubMed] 
23. Long, N.V.; Hien, T.D.; Asaka, T.; Ohtaki, M.; Nogami, M. Synthesis and characterization of Pt-Pd alloy and core-shell bimetallic nanoparticles for direct methanol fuel cells (DMFCs): Enhanced electrocatalytic properties of well-shaped core-shell morphologies and nanostructures. Int. J. Hydrog. Energy 2011, 36, 8478-8491. [CrossRef]

24. Hills, C.W.; Mack, N.H.; Nuzzo, R.G. The Size-Dependent Structural Phase Behaviors of Supported Bimetallic (Pt-Ru) Nanoparticles. J. Phys. Chem. B 2003, 107, 2626-2636. [CrossRef]

25. Alayoglu, S.; Zavalij, P.; Eichhorn, B.; Wang, Q.; Frenkel, A.I.; Chupas, P. Structural and architectural evaluation of bimetallic nanoparticles: A case study of Pt-Ru core-shell and alloy nanoparticles. ACS Nano 2009, 3, 3127-3137. [CrossRef]

26. Park, J.Y.; Zhang, Y.; Grass, M.; Zhang, T.; Somorjai, G.A. Tuning of catalytic CO oxidation by changing composition of Rh-Pt bimetallic nanoparticles. Nano Lett. 2008, 8, 673-677. [CrossRef]

27. Huan, T.N.; Shinde, D.V.; Kim, S.; Han, S.-H.; Artero, V.; Chung, H. Forest of Pt-Au-Ag tri-metallic nanodendrites as an efficient electrocatalyst for methanol oxidation reaction. RSC Adv. 2015, 5, 6940-6944. [CrossRef]

28. Zhang, Y.; Lu, C.; Zhao, G.; Wang, Z. Facile synthesis of gold-platinum dendritic nanostructures with enhanced electrocatalytic performance for the methanol oxidation reaction. RSC Adv. 2016, 6, 51569-51574. [CrossRef]

29. Lou, Y.; Maye, M.M.; Han, L.; Luo, J.; Zhong, C.-J. Gold-platinum alloy nanoparticle assembly as catalyst for methanol electrooxidation. Chem. Commun. 2001, 473-474. [CrossRef]

30. Chen, G.; Xia, D.; Nie, Z.; Wang, Z.; Wang, L.; Zhang, L.; Zhang, J. Facile Synthesis of Co-Pt Hollow Sphere Electrocatalyst. Chem. Mater. 2007, 19, 1840-1844. [CrossRef]

31. Xu, D.; Liu, Z.; Yang, H.; Liu, Q.; Zhang, J.; Fang, J.; Zou, S.; Sun, K. Solution-based evolution and enhanced methanol oxidation activity of monodisperse platinum-copper nanocubes. Angew. Chem. Int. Ed. 2009, 48, 4217-4221. [CrossRef] [PubMed]

32. Liu, Y.; Li, D.; Stamenkovic, V.R.; Soled, S.; Henao, J.D.; Sun, S. Synthesis of Pt3Sn Alloy Nanoparticles and Their Catalysis for Electro-Oxidation of CO and Methanol. ACS Catal. 2011, 1, 1719-1723. [CrossRef]

33. Ren, X.; Lv, Q.; Liu, L.; Liu, B.; Wang, Y.; Liu, A.; Wu, G. Current progress of Pt and Pt-based electrocatalysts used for fuel cells. Sustain. Energ. Fuels 2020, 4, 15-30. [CrossRef]

34. Asset, T.; Job, N.; Busby, Y.; Crisci, A.; Martin, V.; Stergiopoulos, V.; Bonnaud, C.; Serov, A.; Atanassov, P.; Chattot, R.; et al. Porous Hollow PtNi/C Electrocatalysts: Carbon Support Considerations To Meet Performance and Stability Requirements. ACS Catal. 2018, 8, 893-903. [CrossRef]

35. Hu, Y.; Wu, P.; Zhang, H.; Cai, C. Synthesis of graphene-supported hollow Pt-Ni nanocatalysts for highly active electrocatalysis toward the methanol oxidation reaction. Electrochim. Acta 2012, 85, 314-321. [CrossRef]

36. Fang, C.; Zhao, J.; Jiang, R.; Wang, J.; Zhao, G.; Geng, B. Engineering of Hollow PdPt Nanocrystals via Reduction Kinetic Control for Their Superior Electrocatalytic Performances. ACS Appl. Mater. Interfaces 2018, 10, 29543-29551. [CrossRef]

37. Sun, Y.; Mayers, B.T.; Xia, Y. Template-Engaged Replacement Reaction: A One-Step Approach to the Large-Scale Synthesis of Metal Nanostructures with Hollow Interiors. Nano Lett. 2002, 2, 481-485. [CrossRef]

38. Guo, S.; Dong, S.; Wang, E. A general method for the rapid synthesis of hollow metallic or bimetallic nanoelectrocatalysts with urchinlike morphology. Chem. Eur. J. 2008, 14, 4689-4695. [CrossRef]

39. Song, H.M.; Anjum, D.H.; Sougrat, R.; Hedhili, M.N.; Khashab, N.M. Hollow Au@Pd and Au@Pt core-shell nanoparticles as electrocatalysts for ethanol oxidation reactions. J. Mater. Chem. 2012, 22, 25003-25010. [CrossRef]

40. Choi, Y.; Hong, S.; Liu, L.; Kim, S.K.; Park, S. Galvanically replaced hollow Au-Ag nanospheres: Study of their surface plasmon resonance. Langmuir 2012, 28, 6670-6676. [CrossRef]

41. Li, W.; Kuai, L.; Chen, L.; Geng, B. "Re-growth etching" to large-sized porous gold nanostructures. Sci. Rep. 2013, 3, 2377. [CrossRef] [PubMed]

42. Li, C.; Jiang, B.; Imura, M.; Malgras, V.; Yamauchi, Y. Mesoporous Pt hollow cubes with controlled shell thicknesses and investigation of their electrocatalytic performance. Chem. Commun. 2014, 50, 15337-15340. [CrossRef] [PubMed]

43. Guo, S.; Fang, Y.; Dong, S.; Wang, E. High-Efficiency and Low-Cost Hybrid Nanomaterial as Enhancing Electrocatalyst: Spongelike Au/Pt Core/Shell Nanomaterial with Hollow Cavity. J. Phys. Chem. C 2007, 111, 17104-17109. [CrossRef] 
44. Lu, Y.; Zhao, Y.; Yu, L.; Dong, L.; Shi, C.; Hu, M.J.; Xu, Y.J.; Wen, L.P.; Yu, S.H. Hydrophilic Co@Au yolk/shell nanospheres: Synthesis, assembly, and application to gene delivery. Adv. Mater. 2010, 22, 1407-1411. [CrossRef] [PubMed]

45. Papadimitriou, S.; Armyanov, S.; Valova, E.; Hubin, A.; Steenhaut, O.; Pavlidou, E.; Kokkinidis, G.; Sotiropoulos, S. Methanol Oxidation at $\mathrm{Pt}-\mathrm{Cu}, \mathrm{Pt}-\mathrm{Ni}$, and $\mathrm{Pt}-\mathrm{Co}$ Electrode Coatings Prepared by a Galvanic Replacement Process. J. Phys. Chem. C 2010, 114, 5217-5223. [CrossRef]

46. Xia, X.; Wang, Y.; Ruditskiy, A.; Xia, Y. 25th anniversary article: Galvanic replacement: A simple and versatile route to hollow nanostructures with tunable and well-controlled properties. Adv. Mater. 2013, 25, 6313-6333. [CrossRef]

47. Mallin, M.P.; Murphy, C.J. Solution-Phase Synthesis of Sub-10 nm Au-Ag Alloy Nanoparticles. Nano Lett. 2002, 2, 1235-1237. [CrossRef]

48. Sun, Y.; Xia, Y. Mechanistic study on the replacement reaction between silver nanostructures and chloroauric acid in aqueous medium. J. Am. Chem. Soc. 2004, 126, 3892-3901. [CrossRef]

49. Kim, M.H.; Lu, X.; Wiley, B.; Lee, E.P.; Xia, Y. Morphological Evolution of Single-Crystal Ag Nanospheres during the Galvanic Replacement Reaction with $\mathrm{HAuCl}(4)$. J. Phys. Chem. C 2008, 112, 7872-7876. [CrossRef]

50. Jung, N.; Chung, D.Y.; Ryu, J.; Yoo, S.J.; Sung, Y.-E. Pt-based nanoarchitecture and catalyst design for fuel cell applications. Nano Today 2014, 9, 433-456. [CrossRef]

51. Kuai, L.; Wang, S.; Geng, B. Gold-platinum yolk-shell structure: A facile galvanic displacement synthesis and highly active electrocatalytic properties for methanol oxidation with super CO-tolerance. Chem. Commun. 2011, 47, 6093-6095. [CrossRef] [PubMed]

52. You, H.; Zhang, F.; Liu, Z.; Fang, J. Free-Standing Pt-Au Hollow Nanourchins with Enhanced Activity and Stability for Catalytic Methanol Oxidation. ACS Catal. 2014, 4, 2829-2835. [CrossRef]

53. Tan, C.; Sun, Y.; Zheng, J.; Wang, D.; Li, Z.; Zeng, H.; Guo, J.; Jing, L.; Jiang, L. A self-supporting bimetallic $\mathrm{Au} @ \mathrm{Pt}$ core-shell nanoparticle electrocatalyst for the synergistic enhancement of methanol oxidation. Sci. Rep. 2017, 7, 6347. [CrossRef]

54. Shervani, Z.; Ikushima, Y.; Sato, M.; Kawanami, H.; Hakuta, Y.; Yokoyama, T.; Nagase, T.; Kuneida, H.; Aramaki, K. Morphology and size-controlled synthesis of silver nanoparticles in aqueous surfactant polymer solutions. Colloid Polym. Sci. 2007, 286, 403-410. [CrossRef]

55. Lee, W.-K.; Cha, S.-H.; Kim, K.-H.; Kim, B.-W.; Lee, J.-C. Shape-controlled synthesis of gold icosahedra and nanoplates using Pluronic P123 block copolymer and sodium chloride. J. Solid State Chem. 2009, 182, 3243-3248. [CrossRef]

56. Holah, D.G.; Hughes, A.N.; Hui, B.C. Ligand effects upon the reactions of Ni(II) with sodium tetrahydroborate: $\mathrm{Ni}(\mathrm{I})$ complexes of bipyridyl and 1,10-phenanthroline. Can. J. Chem. 1977, 55, 4048-4055. [CrossRef]

57. Au, L.; Lu, X.; Xia, Y. A Comparative Study of Galvanic Replacement Reactions Involving Ag Nanocubes and $\mathrm{AuCl}(2)$ or $\mathrm{AuCl}(4)$. Adv. Mater. 2008, 20, 2517-2522. [CrossRef]

58. Zhang, Q.; Xie, J.; Lee, J.Y.; Zhang, J.; Boothroyd, C. Synthesis of Ag@AgAu metal core/alloy shell bimetallic nanoparticles with tunable shell compositions by a galvanic replacement reaction. Small 2008, 4, 1067-1071. [CrossRef]

59. Papaderakis, A.; Mintsouli, I.; Georgieva, J.; Sotiropoulos, S. Electrocatalysts Prepared by Galvanic Replacement. Catalysts 2017, 7, 80. [CrossRef]

60. Chen, L.; Zhao, W.; Jiao, Y.; He, X.; Wang, J.; Zhang, Y. Characterization of Ag/Pt core-shell nanoparticles by UV-vis absorption, resonance light-scattering techniques. Spectrochim. Acta A 2007, 68, 484-490. [CrossRef]

61. Li, K.; Jin, Z.; Ge, J.; Liu, C.; Xing, W. Platinum nanoparticles partially-embedded into carbon sphere surfaces: A low metal-loading anode catalyst with superior performance for direct methanol fuel cells. J. Mater. Chem. A 2017, 5, 19857-19865. [CrossRef]

62. Brankovic, S.R.; Wang, J.X.; Adžić, R.R. Metal monolayer deposition by replacement of metal adlayers on electrode surfaces. Surf. Sci. 2001, 474, L173-L179. [CrossRef]

63. Zhu, J.; Lyu, Z.; Chen, Z.; Xie, M.; Chi, M.; Jin, W.; Xia, Y. Facile Synthesis and Characterization of Pd@IrnL ( $\mathrm{n}=1-4)$ Core-Shell Nanocubes for Highly Efficient Oxygen Evolution in Acidic Media. Chem. Mater. 2019, 31, 5867-5875. [CrossRef]

64. Yang, L.; Li, G.; Chang, J.; Ge, J.; Liu, C.; Vladimir, F.; Wang, G.; Jin, Z.; Xing, W. Sea urchin-like Aucore@Pdshell electrocatalysts with high FAOR performance: Coefficient of lattice strain and electrochemical surface area. Appl. Catal. B 2020, 260, 118200. [CrossRef] 
65. Xu, Y.; Lin, X. Facile fabrication and electrocatalytic activity of Pt0.9Pd0.1 alloy film catalysts. J. Power Sources 2007, 170, 13-19. [CrossRef]

66. Hu, Y.; Zhang, H.; Wu, P.; Zhang, H.; Zhou, B.; Cai, C. Bimetallic Pt-Au nanocatalysts electrochemically deposited on graphene and their electrocatalytic characteristics towards oxygen reduction and methanol oxidation. Phys. Chem. Chem. Phys. 2011, 13, 4083-4094. [CrossRef]

67. Sanders, C.I.; Martin, D.S., Jr. Acid Hydrolysis of $\left[\mathrm{PtCl}_{4}\right]=$ and $\left[\mathrm{PtCl}_{3}\left(\mathrm{H}_{2} \mathrm{O}\right)\right]^{-1}$. J. Am. Chem. Soc. 1961, 83, 807-810. [CrossRef]

68. Yu, Y.-T.; Xu, B.-Q. Effect of Precursor Hydrolysis on Shape-controlled Synthesis of Pt Nanocrystals. Acta Chim. Sin. 2003, 6, 1758-1764.

Publisher's Note: MDPI stays neutral with regard to jurisdictional claims in published maps and institutional affiliations.

(C) 2020 by the authors. Licensee MDPI, Basel, Switzerland. This article is an open access article distributed under the terms and conditions of the Creative Commons Attribution (CC BY) license (http://creativecommons.org/licenses/by/4.0/). 